\title{
Biological Effects of Light-Emitting Diodes Curing Unit on MDPC-23 Cells and Lipopolysaccharide Stimulated MDPC-23 Cells
}

\author{
Moon-Jin Jeong ${ }^{1}$ and Soon-Jeong Jeong ${ }^{2, \dagger}$ \\ ${ }^{1}$ Department of Oral Histology and Developmental Biology, School of Dentistry, Chosun University, Gwangju 61452, \\ ${ }^{2}$ Department of Dental Hygiene, College of Health Science, Youngsan University, Yangsan 50510, Korea
}

\begin{abstract}
Background: Light-emitting diodes curing unit (LCU), which emit blue light, is used for polymerization of composite resins in many dentistry. Although the use of LCU for light-cured composite resin polymerization is considered safe, it is still controversial whether it can directly or indirectly have harmful biological influences on oral tissues. The aim of this study was to elucidate the biological effects of LCU in wavelengths ranging from 440 to $490 \mathrm{~nm}$, on the cell viability and secretion of inflammatory cytokines in MDPC-23 odontoblastic cells and inflammatory-induced MDPC-23 cells by lipopolysaccharide (LPS).

Methods: The MTT assay and observation using microscope were performed on MDPC-23 cells to investigate the cell viability and cytotoxic effects on LCU irradiation.

Results: MDPC-23 cells and LPS stimulated MDPC-23 cells were found to have no effects on cell viability and cell morphology in the LCU irradiation. Nitric oxide (NO) and prostaglandin $\mathrm{E}_{2}$ which are the pro-inflammatory mediators, and interleukin- $1 \beta$ and tumor necrosis factor- $\alpha$ (TNF- $\alpha$ ) which are the proinflammatory cytokines were significantly increased in MCPD-23 cells after LCU irradiation as time increased in comparison with the control. LCU irradiation has the potential to induce inflammation or biological damages in normal dental tissues, including MDPC-23 cells.

Conclusion: Therefore, it is necessary to limit the use of LCU except for the appropriate dose and irradiation time. In addition, LCU irradiation of inflammatory-induced MDPC-23 cells by LPS was reduced the secretion of NO compared to the LPS alone treatment group and was significantly reduced the secretion of TNF- $\alpha$ in all the time groups. Therefore, LCU application in LPS stimulated MDPC-23 odontoblastic cells has a photodynamic therapy like effect as well as inflammation relief.
\end{abstract}

Key Words: Inflammation, Light-emitting diodes curing unit, Lipopolysaccharide, MDPC-23 cell, Photodynamic therapy

\section{Introduction}

The tooth-colored composite resin used for restoration has been widely used since its introduction in the dental field in the 1970s due to the increasing problems of dental amalgam and demand for esthetic restoration of patients ${ }^{1)}$. In addition, the use of tooth-colored composite resin in posterior restorations as well as anterior restorations has increased and it is also used for the bonding of stainlesssteel brackets and ceramic brackets in orthodontic treatment ${ }^{2,3)}$. In aesthetic dental restorations, the tooth- colored composite resin is polymerized by the energy of the laser produced by light curing units ${ }^{4}$. Activated toothcolored composite resins that do not receive sufficient energy by the light curing units break down along the restored margins, weaken the bond strength with the tooth, and lack hardness ${ }^{5}$. Therefore, the light curing units have been developed with the rapid increase of the aesthetic dental restorative technique using the light-cured composite resins $^{6}$. There are three types of light curing units that are mainly used in dentistry for light-cured composite resins polymerization, and these three types of LCU have 
different light sources, namely, halogen curing units (HCU), light-emitting-diode curing units (LCU) and plasma arc curing units $(\mathrm{PCU})^{4)}$. HCU has disadvantages in that only a small amount of the total energy is used for the polymerization of the light-cured composite resins and most of the energy generates heat, resulting in poor energy efficiency and long timings for polymerization ${ }^{4)}$. LCU and PCU have been developed to complement the shortcomings of HCU and to reduce the clinical chair time used for light curing time ${ }^{5,6)}$. PCU has a very high energy intensity of more than $2,000 \mathrm{~mW} / \mathrm{cm}^{2}$, which enables polymerization of the light-cured composite resins in a short time, but the rigidity of the composite resin during polymerization is significantly low, shrinkage is large, and it is very expensive $^{7)}$. Light-emitting diodes (LEDs), introduced in 1990s, consist of a combination of two semiconductors and are an effective method of converting electrical energy into light or laser ${ }^{6}$. The LCU, that uses LEDs as light source, generates up to $1,100 \mathrm{~mW} / \mathrm{cm}^{2}$ energy at a wavelength of $402 \sim 600 \mathrm{~nm}$ and has a semi-permanent, low price, and provide a strong vibration and shock resistance $^{6}$. Therefore, LCU, which is seen as blue light, is used for polymerization of composite resins in many dentistry ${ }^{8)}$. Although the use of light curing unit for polymerization of composite resin is considered safe, its safety is controversial whether it can directly or indirectly have harmful biological influences on oral tissues, including dental and non-dental tissues ${ }^{9,10)}$. Studies on the biological effects of light irradiation of LCUs using oral cell-derived cell lines are not sufficient ${ }^{6}$. MDPC-23 cells are odontoblastic cells derived from dental papilla of fetal mouse molars. Odontoblast is a representative dental tissue cell that produces most of the extracellular matrix of dentin and is involved in mineralization of dentin ${ }^{11)}$. Odontoblast is directly influenced by LCU irradiation during resin polymerization in dental treatment when exposed to dental pulp and deep cavities ${ }^{4}$.

We applied a LCU of blue light with distinct wavelengths ranging from 440 to $490 \mathrm{~nm}$, which is widely used for polymerization of light-cured composite resins in dental clinics, for the most commonly used 20 seconds in other to evaluate biological effects on the cell viability and secretion of inflammatory cytokines in MDPC-23 odontoblastic cells and inflammatory-induced MDPC-23 cells by lipopolysaccharide (LPS).

\section{Materials and Methods}

\section{Cell culture and LCU irradiation}

MDPC-23 cells were obtained from Dr. CT Hanks of University of Michigan (Ann Arbor, MI, USA). Cells were cultured in Dulbecco's modified Eagle's medium (DMEM; Gibco-BRL, New York, NY, USA) supplemented with a $1 \%$ antibiotic-antimycotic solution (Gibco-BRL) and $10 \%$ fetal bovine serum (Gibco-BRL). Cells were maintained in a humidified $\mathrm{CO}_{2}$ incubator at $37^{\circ} \mathrm{C}$.

LCU is a Dmetec Skylight product (Dmetec, Bucheon, Korea) with a wavelength of $440 \sim 490 \mathrm{~nm}$, which is widely used in dental clinics (Table 1). Cells were irradiated with LCU under the same conditions as when polymerizing a resin using LCU in dental clinic and the LCU held $2 \mathrm{~cm}$ away from the cells during exposure. The cells were divided into four groups as follows: the control, LPS alone treatment $(100 \mathrm{ng} / \mathrm{ml})$, LCU alone irradiation, and cotreatment group of LPS and LCU.

\section{MTT assay}

The cell viability and cytotoxic effects were assessed using a 3-(4,5-dimethylthiazol-2-yl)-2,5-diphenyltetrazolium bromide (MTT) assay. The MDPC-23 cells were seeded in 48-well plates and treated with $100 \mathrm{ng} / \mathrm{ml} \mathrm{LPS}$, irradiated with LCU for 20 seconds, or co-treated with

Table 1. Information and Characteristics of LED Curing Unit (LCU)

\begin{tabular}{lc}
\hline \multicolumn{1}{c}{ Item } & LCU \\
\hline $\begin{array}{l}\text { Light source } \\
\text { Model (company) }\end{array}$ & LED \\
Wavelength $(\mathrm{nm})$ & Skylight (Dmetec, Korea) \\
Output intensity & $440 \sim 490$ \\
(radiant flux) $\left(\mathrm{mW} / \mathrm{cm}^{2}\right)$ & $1,000 \sim 2,400$ \\
Time of exposure $\left(\mathrm{clinical}^{2}\right.$ & 20 \\
based) (s) & 20 \\
$\begin{array}{l}\text { Dose of light }\left(\mathrm{J} / \mathrm{cm}^{2}\right) \\
\text { Characteristics }\end{array}$ & $\begin{array}{c}\text { Fast curing/sterilization for } \\
13 \sim 11 \mathrm{~mm}\end{array}$ \\
& $\begin{array}{c}\text { Multiple function with versatility } \\
\text { by different composite resin }\end{array}$ \\
\hline
\end{tabular}

LED: light-emitting diodes. 
LPS and LCU and then incubated for 0, 24, and 48 hours.

\section{Microscopic observation}

The culture medium was removed from the cells that were then washed three times with PBS and then fixed using a solution containing $3.7 \%$ formaldehyde (Sigma Chemical, St. Louis, MO, USA). The images of cells were obtained using an inverted phase contrast microscope (Carl Zeiss, Oberkochen, Germany).

\section{NO production}

Nitric oxide (NO) production was measured in cell supernatants of LPS alone treated, LCU alone irradiated, and LPS and LCU co-treated cell using the NO assay kit (R\&D systems, Minneapolis, MN, USA). A 2-fold diluted culture supernatant was transferred to 96-well plate, and an equal amount of Griess reagent was added. The plate was then incubated for 10 minutes, and the absorbance was measured at $540 \mathrm{~nm}$ on a microplate reader (BioTek Instruments, Winooski, VT, USA). The amount of NO was calculated using sodium nitrite standard curve.

\section{5. $\mathrm{PGE}_{2}$ ELISA}

The concentration of prostaglandin $\mathrm{E}_{2}\left(\mathrm{PGE}_{2}\right)$ was measured in cell supernatants using the $\mathrm{PGE}_{2}$

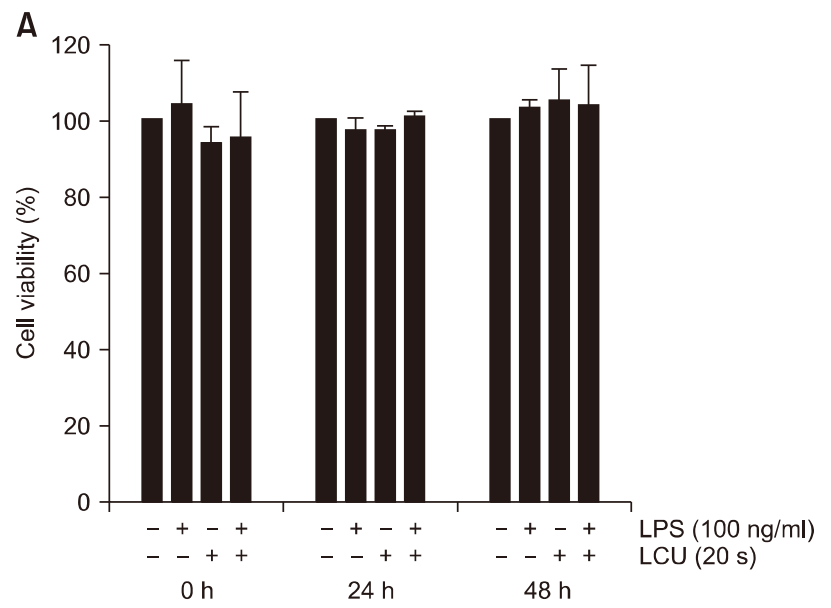

enzyme-linked immunosorbent assay (ELISA) kit (R\&D systems). The absorbance was recorded at $490 \mathrm{~nm}$ using a microplate reader (BioTek Instruments). The $\mathrm{PGE}_{2}$ concentration in cell supernatants was determined using a $\mathrm{PGE}_{2}$ standard curve.

\section{Western blotting}

MDPC-23 cells were lysed using an NP-40 containing lysis buffer $(150 \mathrm{mM} \mathrm{NaCl}, 1 \% \mathrm{NP}-40,50 \mathrm{mM}$ Tris- $\mathrm{HCl}$ [pH 7.4], $2 \mathrm{mM} \mathrm{Na}_{3} \mathrm{VO}_{4}, 2 \mathrm{mM} \mathrm{Na}{ }_{4} \mathrm{P}_{2} \mathrm{O}_{7}, 50 \mathrm{mM} \mathrm{NaF}, 2$ mM EDTA [pH 7.4], $0.1 \mu \mathrm{g} / \mathrm{ml}$ leupeptin, and $1 \mu \mathrm{g} / \mathrm{ml}$ aprotinin). Following, the total protein concentration of the samples was estimated using protein estimation kit (Bio-Rad, Hercules, CA, USA) and $30 \mu \mathrm{g}$ of the protein samples was subjected electrophoresis in $10 \%$ SDSpolyacrylamide gel. After electrophoresis, the protein was transferred to a polyvinylidene difluoride (PVDF) membrane (Merck Millipore, Darmstadt, Germany). The membrane was blocked with $5 \%$ bovine serum albumin (Bioshop, Burlington, Canada) for 1 hour. The membranes were blotted with 1:1,000 anti-rabbit interleukin-1 $\beta$ (IL-1 $\beta$ ) and tumor necrosis factor- $\alpha$ (TNF- $\alpha$ ) antibodies (Abcam, Cambridge, United Kingdom), and 1:2,500 anti-mouse $\beta$-actin antibody (Santa Cruz Biotechnology, Dallas, TX, USA) for 16 hours at $4^{\circ} \mathrm{C}$. After washing, the membrane
B

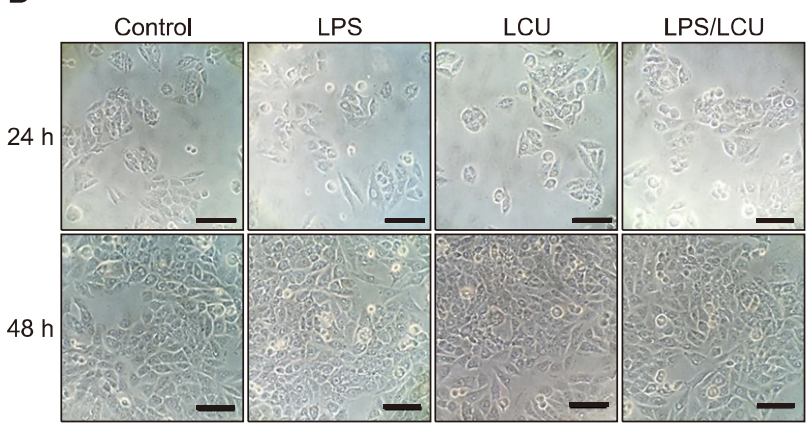

Fig. 1. Effects of light-emitting diodes curing unit (LCU) irradiation on cell viability and morphology of MDPC-23 cells and lipopolysaccharide (LPS) stimulated MDPC-23 cells. The cells were irradiated for 20 seconds using LCU with wavelengths of 440 to 490 $\mathrm{nm}$ and LPS was treated with $100 \mathrm{ng} / \mathrm{ml}$. (A) The cell viability on LCU irradiation was assessed with MTT assay. The results obtained from three independent experiments were expressed as a ratio of values in the surviving cell to the values in the control group (no treatment group of LPS and LCU), and the values were expressed as mean \pm standard deviation. (B) Morphological changes of MDPC-23 cells by the LPS alone treatment, the LCU alone irradiation and co-treatment group of LPS and LCU were observed by inverted phase contrast microscope. Scale bars $=60 \mu \mathrm{m}$. 
was probed with 1:5,000 HRP-conjugated goat anti-rabbit or goat anti-mouse secondary antibody (Santa Cruz Biotechnology) for 1 hour. The signals were developed on X-ray film (Fuji Film, Tokyo, Japan) after detection using an ECL solution (Merck Millipore). The intensities of bands corresponding to respective proteins were measured using Science Lab Image Gauge (Fuji Film).

\section{Statistical analysis}

All experiments were carried out in triplicate. All the data is reported as the mean and standard deviation determined using Microsoft Excel 2010 software (Microsoft, Redmond, WA, USA). The significant differences $(\mathrm{p}<0.05, \mathrm{p}<0.01)$ were determined using a Student's t-test.

\section{Results}

1. Effect of LCU irradiation on the cell viability and morphology of MDPC-23 cells and LPS stimulated MDPC-23 cells

The cells were irradiated for 20 seconds using LCU within 440 to $490 \mathrm{~nm}$ wavelength range, which is widely used for composite resin polymerization in actual clinical practice. Cells were also induced inflammation with 100 $\mathrm{ng} / \mathrm{ml}$ of LPS, and each treatment group was incubated for 0,24 , and 48 hours. The MTT assay was performed to investigate the cell viability and cytotoxicity of LCU irradiation on MDPC-23 cells. MDPC-23 cells were found to have no significant effects on the cytotoxicity and cell viability in all the three group, i.e., LCU alone irradiation, LPS alone treatment and the co-treatment group of LCU and LPS (Fig. 1A). The morphological changes were observed under microscope, and the elongation of the protrusions was seen in the LPS alone treated and in the co-treatment group of LPS and LCU, however, no morphological change was observed in the LCU irradiation alone group (Fig. 1B).

\section{Effects of $L C U$ irradiation on $N O$ and $P G E_{2}$ production of MDPC-23 cells and LPS stimulated MDPC-23 cells}

The production of NO by MDPC-23 cells was significantly increased in comparison to the control, depending on LPS treatment, regardless of whether or not the LCU irradiation, but there was no change in LCU irradiation alone group ( $\mathrm{p}<0.05$; Fig. 2A). On the other hand, co-treatment group of LCU and LPS at 24 hours showed a decrease in the amount of NO compared to the 24 hours LPS alone treatment group but the differences were not found to be significant (Fig. 2A). The production of $\mathrm{PGE}_{2}$ in MDPC-23 cells was also significantly increased following LPS treatment, regardless of the presence or absence of LCU irradiation $(\mathrm{p}<0.05, \mathrm{p}<$

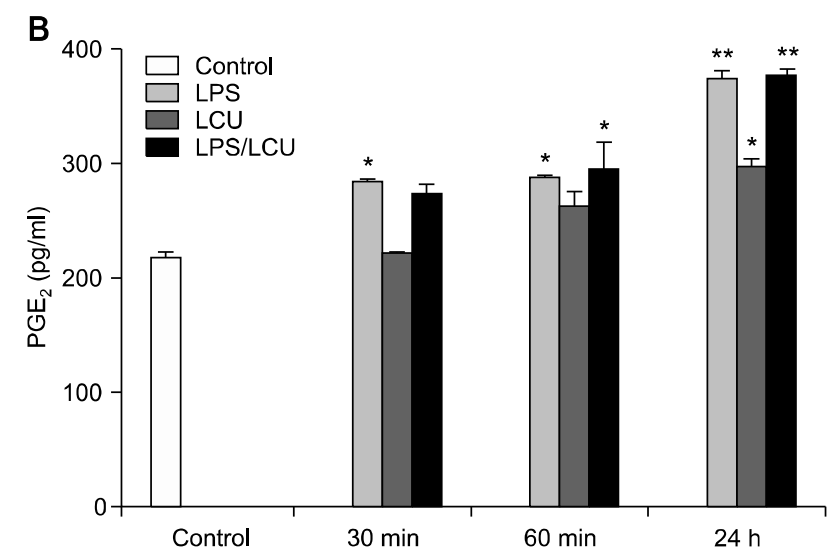

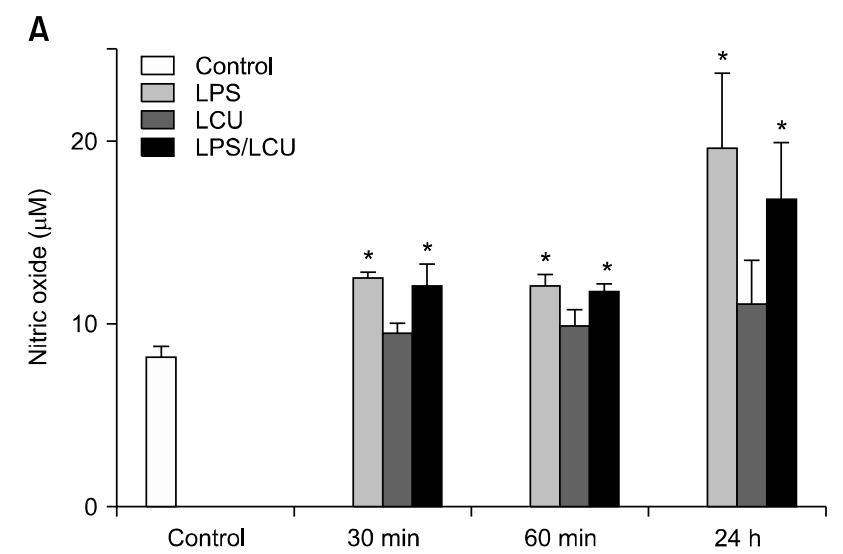

Fig. 2. Effects of light-emitting diodes curing unit (LCU) irradiation on nitric oxide and prostaglandin $E_{2}$ (PGE 2 ) production of MDPC-23 cells and lipopolysaccharide (LPS) stimulated MDPC-23 cells. MDPC-23 cells were irradiated for 20 seconds using LCU and LPS was treated with $100 \mathrm{ng} / \mathrm{ml}$. The values of nitric oxide (A) and $\mathrm{PGE}_{2}$ (B) were measured in the supernatants of the culture medium using the Griess reaction and a commercial enzyme-linked immunosorbent assay kit. Values are represented the mean \pm standard deviation of results obtained in three independent experiments. $* p<0.05$ and $* \star p<0.01$ compared with the control group. 
0.01) and the LCU irradiation alone group showed a slight increase in $\mathrm{PGE}_{2}$ production with time but there was no significant difference. However, significant increase in $\mathrm{PGE}_{2}$ production could be confirmed for LCU alone irradiation group only after 24 hours $(\mathrm{p}<0.05, \mathrm{p}<0.001$; Fig. 2B). These results indicate that MDPC-23 cells are affected by LCU irradiation alone and increase the production of $\mathrm{NO}$ and $\mathrm{PGE}_{2}$. On the other hand, in the case of MDPC-23 cells induced to inflammation by LPS treatment, the production of NO decreased by the LCU irradiation compared to the LPS alone treatment.

\section{Effects of LCU irradiation on IL-1 $\beta$ and TNF- $\alpha$ production of in MDPC-23 cells and LPS stimulated MDPC-23 cells}

IL-1 $\beta$ and TNF- $\alpha$ which are pro-inflammatory cytokines, were investigated in order to elucidate the biological effects of LCU irradiation on MDPC-23 cells because LCU irradiation has different effects depending upon the type of pro-inflammatory mediators and cell lines. The amount of IL- $1 \beta$ by LCU alone irradiated the MDPC-23 cells was either greater or similar to that in case of LPS alone treatment. However, the amount of secretion of IL-1 $\beta$ was significantly increased with time in comparison to the control $(\mathrm{p}<0.01$; Fig. 3A, 3B). However, the production of IL-1 $\beta$ in the co-treatment group of LPS and LCU at 60 minutes and 24 hours was slightly decreased compared to the levels in case of LPS treatment and LCU irradiation alone group, there was significant difference in that of 24 hours ( $<<0.01$; Fig. 3A, 3B). The amount of TNF- $\alpha$ secretion in LCU irradiated MDPC-23 cells was significantly increased at 30 minutes and 24 hours group compared to the control (Fig. 3A, 3C). In particular, the amount of TNF- $\alpha$ in LCU alone irradiated group at 30 minutes was higher than that in LPS alone treatment at 30 minutes (Fig. 3C). In addition, the amount of TNF- $\alpha$ secretion in the co-treatment group of LPS and LCU of MDPC-23 cells was significantly reduced compared to the
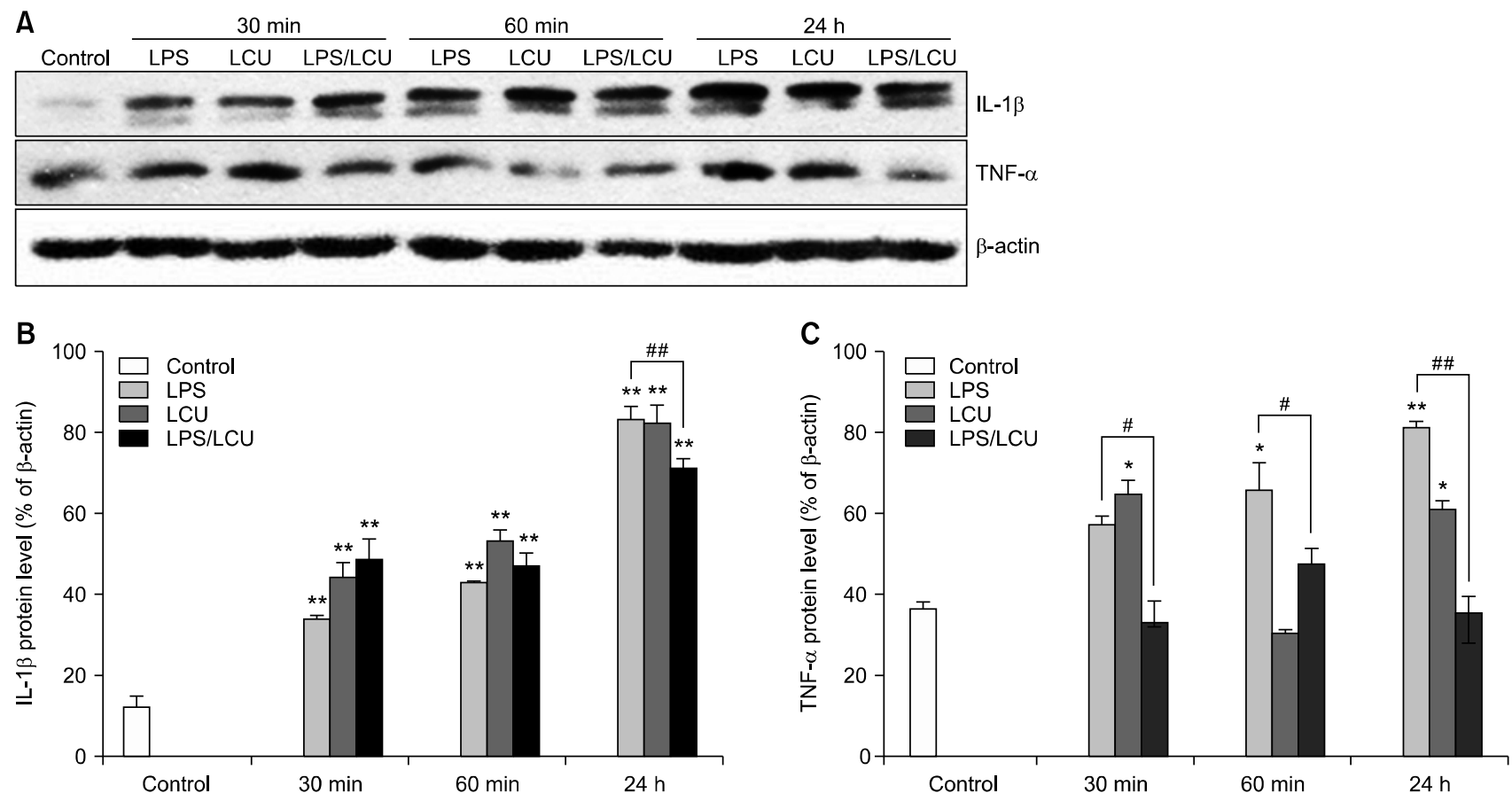

Fig. 3. Total protein expression of interleukin-1 $\beta(\mathrm{IL}-1 \beta)$ and tumor necrosis factor $-\alpha(\mathrm{TNF}-\alpha)$ by the light-emitting diodes curing unit (LCU) irradiation in MDPC-23 cells and lipopolysaccharide (LPS) stimulated MDPC-23 cells. The cells were irradiated with LCU for 20 seconds and LPS $(100 \mathrm{ng} / \mathrm{ml})$ was treated. (A) Total protein was extracted from the MDPC-23 cells and was subjected to western blot analysis using indicated antibodies. Actin was used as internal control for the western blot assays. The values of IL-1 $\beta$ (B) and TNF- $\alpha$ (C) in the culture supernatants were measured by commercial enzyme-linked immunosorbent assay kits. Value are represented the mean \pm standard deviation of results from three independent experiments. $* p<0.05$ and $\star * p<0.01$ compared with the control group. ${ }^{\#}<0.05$ and ${ }^{\# \#} p<0.01$ compared with the LPS groups. 
LPS alone treated group in the corresponding time period (Fig. 3C). In other words, MDPC-23 cells increase the secretion of TNF- $\alpha$ in LCU irradiation. These results indicate that MDPC-23 cells show inflammatory response to LCU irradiation. In addition, LCU irradiation of LPS treated MDPC-23 cells resulted in a significant reduction in the secretion of TNF- $\alpha$ in all time groups. These results indicate that LCU irradiation in inflammatory conditions is effective in relief of inflammation.

\section{Discussion}

MTT assay is widely used as an indirect but accurate and useful method to confirm the effect of DNA synthesis on cytotoxicity, cell viability and morphology ${ }^{12)}$. There are many previous reports of MTT assays that have been shown to influence the proliferation of various cell lines following light irradiation of various sources ${ }^{6,12}$. The results have shown that the possibility of cell proliferation is gradually decreasing, which is due to inhibition of mitosis $^{12)}$, inhibition of mitochondrial activity ${ }^{13)}$, and oxidative stress ${ }^{13)}$ resulting from DNA damage ${ }^{12)}$ and the production of reactive oxygen species $(\mathrm{ROS})^{12)}$. In this study, LCU irradiation for 20 seconds was used to treat MDPC-23 odontoblastic cell line derived from dental papilla, which is a widely used method for tooth-colored composite resin polymerization in dental clinics. As a result, the cell viability and morphology of MDPC-23 cells were not affected by LCU irradiation. These results are attributed to differences in the types of cells and light doses than previously reported. Previous studies have often been unclear in terms of the intensity and duration of light, and the conditions reported were also different from the way this technique is applied to dental treatment ${ }^{4,14)}$. In this study, the conditions of LCU light irradiation were set and applied in accordance with the method commonly followed in dental clinical practice. The amount of irradiation dose of LCU in this study is very small compared to that reported previously. Thus, the present irradiation dose of LCU was found to have no effect on the cell viability and morphology of MDPC-23 cells, indicating the absence of any risks of LCU irradiation. However, increasing irradiation doses and times may have the potential to affect the cell viability and morphology of MDPC-23 cells. This possibility is confirmed by the significant increase in the secretion of $\mathrm{NO}$ and $\mathrm{PGE}_{2}$ which are the pro-inflammatory mediators, and IL- $1 \beta$ and TNF- $\alpha$ which are the proinflammatory cytokines after 24 hours of LCU irradiation in normal MDPC-23 cells. NO is an easily diffusible and water-soluble gas and free radical. High levels of secreted $\mathrm{NO}$ activate surrounding host cells and cause tissue damage ${ }^{15}$. $\mathrm{PGE}_{2}$ is also involved in pain and heat generation in inflammatory and immune responses ${ }^{15}$. $\mathrm{NO}$ and $\mathrm{PGE}_{2}$ are pro-inflammatory mediators that play an important role early in the inflammatory response and are secreted by the stimulation of inflammatory factors such as LPS, TNF- $\alpha$, and interferon- $\gamma^{16,17)}$. IL-1 $\beta$, which is produced by macrophages or immune-related cells during inflammation, and TNF- $\alpha$, which mediates the inflammatory response, are proinflammatory cytokines that are mainly used as indicators of inflammatory states of the cell since their secretion is increased during inflammation ${ }^{18)}$. The expression of proinflammatory genes such as those encoding $\mathrm{NO}, \mathrm{PGE}_{2}$, IL- $1 \beta$, and TNF- $\alpha$ is increased by LPS stimulation because of the transcriptional factor nuclear factor kappa $\mathrm{B}(\mathrm{NF}-\mathrm{kB})$, that remains complexed in the cytoplasm with inhibitory kappa $\mathrm{B}(\mathrm{I} \kappa \mathrm{B})^{18-20)}$. IкB degradation occurs following stimulation with LPS, and the released NF-אB enters the nucleus and acts as a transcription factor resulting in increased expression of proinflammatory genes ${ }^{18,21)}$. These results are also related to the outcome of a continuous process of heat generation and reaction through the photoreceptor ${ }^{22,23)}$. The production of heat has a negative effect on living cells, tissues and their regeneration process ${ }^{24,25)}$, light absorption through flavins and cytochromes induces production of ROS in the cell, disturbing the function of $\mathrm{DNA}^{26}$, mitosis of cells ${ }^{27)}$, and mitochondria ${ }^{10}$. In particular, flavins and cytochromes that respond to blue light generated by LCU are the photoreceptors linked to the mitochondrial respiratory chain ${ }^{28,29)}$. Absorbed blue light from LCU induces oxidative stress ${ }^{12)}$ and secretion of inflammatory cytokines through the activity of transcription factors such as $N F-K^{30)}$. This is the first report revealing the inflammatory effect of LCU irradiation on the MDPC-23 odon- 
toblastic cells. LCU irradiation has the potential to induce inflammation or biological damages in the normal dental tissues, including MDPC-23 cells. Therefore, it is necessary to limit the use of LCU except at the appropriate dose and for a irradiation time.

The report of on the non-invasive photodynamic therapy (PDT) shows that irradiation with low-energy light source has a dramatic effect on inflammation relief and wound healing, and is available for treatment ${ }^{23)}$. Although the advent PDT was for the treatment of cancer, PDT has also found applications in wound healing ${ }^{22,23)}$, venous leg ulcers ${ }^{31)}$, pain relief ${ }^{32)}$, rheumatoid arthritis ${ }^{33)}$, skin diseases, skin cancer ${ }^{14)}$ and periodontal diseases ${ }^{23)}$. In particular, low-level light energy lasers in PDT have been reported to inhibit inflammation by inhibiting the expression of proinflammatory cytokines such as IL- $1 \beta$ and TNF- $\alpha$ besides increasing the secretion of anti-inflammatory cytokines such as SLPI ${ }^{18)}$. In the dental field, low-level light energy lasers are used for periodontal disease, peri-implantitis, dental hypersensitivity, gingivitis, and intraoral ulceration. There are recent reports highlighting the use of PDT equipment using LEDs with low-level light energy commercially ${ }^{34,35)}$.

In this study, when LCU with low-level light energy was applied to inflammatory-induced MDPC-23 cells by LPS, interestingly, NO production was reduced compared to the LPS alone treatment group and TNF- $\alpha$ secretion were significantly decreased and as mentioned above the effect similar to that observed in PDT was achieved following LCU irradiation of LPS treated cells. It was interesting to have a PDT like effect when the irradiation dose and time of LCU used were those that are commonly used in the practice. Thus, LCU application on inflammation-induced MDPC-23 odontoblastic cells has a PDT like effect as well as inflammation relief.

\section{Notes}

\section{Conflict of interest}

No potential conflict of interest relevant to this article was reported.

\section{Ethical approval}

Not applicable.

\section{ORCID}

Moon-Jin Jeong, https://orcid.org/0000-0002-5547-898X

Soon-Jeong Jeong, https://orcid.org/0000-0002-8959-4663

\section{Acknowledgements}

This work was supported by a 2017 research grant from Youngsan University, Republic of Korea.

\section{References}

1. Wataha JC, Lockwood PE, Bouillaguet S, Noda M: In vitro biological response to core and flowable dental restorative materials. Dent Mater 19: 25-31, 2003.

2. Oesterle LJ, Newman SM, Shellhart WC: Rapid curing of bonding composite with a xenon plasma arc light. Am J Orthod Dentofacial Orthop 119: 610-616, 2001. https://doi.org/10.1067/mod.2001.113652

3. Klocke A, Korbmacher HM, Huck LG, Kahl-Nieke B: Plasma arc curing lights for orthodontic bonding. Am J Orthod Dentofacial Orthop 122: 643-648, 2002. https://doi.org/10.1067/mod.2002.126897

4. Yalcin M, Kenar H, Dayi B, Sisman R, Karaoz E: The effect of light curing units on proliferation and senescence of human dental pulp mesenchymal stem cells. Int J Dent Sci Res 4: 10-16, 2016.

5. Aguiar FH, Braceiro A, Lima DA, Ambrosano GM, Lovadino JR: Effect of light curing modes and light curing time on the microhardness of a hybrid composite resin. J Contemp Dent Pract 8: 1-8, 2007.

6. Ergun G, Egilmez F, Cekic-Nagas I: The effect of light curing units and modes on cytotoxicity of resin-core systems. Med Oral Patol Oral Cir Bucal 15: 962-968, 2010. https://doi.org/10.4317/medoral.15.e962

7. Peutzfeldt A, Sahafi A, Asmussen E: Characterization of resin composites polymerized with plasma arc curing units. Dent Mater 16: 330-336, 2000. https://doi.org/10.1016/S0109-5641(00)00025-7

8. Thind BS, Stirrups DR, Lloyd CH: A comparison of tungsten-quartz-halogen, plasma arc and light-emitting diode light sources for the polymerization of an orthodontic 
adhesive. Eur J Orthod 28: 78-82, 2006.

https://doi.org/10.1093/ejo/cji076

9. Wataha JC, Lockwood PE, Lewis JB, Rueggeberg FA, Messer RL: Biological effects of blue light from dental curing units. Dent Mater 20: 150-157, 2004. https://doi.org/10.1016/S0109-5641(03)00086-1

10. Lockwood DB, Wataha JC, Lewis JB, Tseng WY, Messer RL, Hsu SD: Blue light generates reactive oxygen species (ROS) differentially in tumor vs. normal epithelial cells. Dent Mater 21: 683-688, 2005.

https://doi.org/10.1016/j.dental.2004.07.022

11. Goldberg M, Smith AJ: Cells and extracellular matrices of dentin and pulp: a biological basis for repair and tissue engineering. Crit Rev Oral Biol Med 15: 13-27, 2004.

12. Wataha JC, Lewis JB, Lockwood PE, Noda M, Messer RL, Hsu S: Response of THP-1 monocytes to blue light from dental curing lights. J Oral Rehabil 35: 105-110, 2008. https://doi.org/10.1111/j.1365-2842.2007.01806.x

13. Rotenberg S, Lewis JB, Lockwood PE, et al.: Extracellular environment as one mediator of blue light-induced mitochondrial suppression. Dent Mater 22: 759-764, 2006. https://doi.org/10.1016/j.dental.2005.11.003

14. Liebmann J, Born M, Kolb-Bachofen V: Blue-light irradiation regulates proliferation and differentiation in human skin cells. J Invest Dermatol 130: 259-269, 2010. https://doi.org/10.1038/jid.2009.194

15. Moncada S, Higgs A: The L-arginine-nitric oxide pathway. $\mathrm{N}$ Engl J Med 329: 2002-2012, 1993. https://doi.org/10.1056/NEJM199312303292706

16. Klapproth JM, Sasaki M: Bacterial induction of proinflammatory cytokines in inflammatory bowel disease. Inflamm Bowel Dis 16: 2173-2179, 2010. https://doi.org/10.1002/ibd.21332

17. Striz I, Brabcova E, Kolesar L, Sekerkova A: Cytokine networking of innate immunity cells: a potential target of therapy. Clin Sci (Lond) 126: 593-612, 2014. https://doi.org/10.1042/CS20130497

18. Jeong SJ, Choi BD, Lee HY, et al.: $660 \mathrm{~nm}$ Red LED induces secretory leukocyte protease inhibitor (SLPI) in lipopolysaccharide-stimulated RAW264.7 cell. J Nanosci Nanotechnol 15: 5610-5616, 2015. https://doi.org/10.1166/jnn.2015.10465

19. Lee HO, Park JY: Antibacterial effect and cytotoxicity of desensitizer containing antimicrobial. J Dent Hyg Sci 15:
238-245, 2015. https://doi.org/10.17135/jdhs.2015.15.2.238

20. Lee SI: The role of NFATc1 on osteoblastic differentiation in human periodontal ligament cells. J Dent Hyg Sci 15: 488-494, 2015. https://doi.org/10.17135/jdhs.2015.15.4.488

21. Lee DE, Kim JH, Shin DH, Cha JH, Bak EJ, Yoo YJ: Odontoclast and osteoclast formation in rats with ligatureinduced periodontitis. J Dent Hyg Sci 15: 295-300, 2015. https://doi.org/10.17135/jdhs.2015.15.3.295

22. Geminiani A, Caton JG, Romanos GE: Temperature change during non-contact diode laser irradiation of implant surfaces. Lasers Med Sci 27: 339-342, 2012. https://doi.org/10.1007/s10103-010-0876-8

23. Cho KW, Lee SY, Chang BS, Um HS, Lee JK: The effect of photodynamic therapy on Aggregatibacter actinomycetemcomitans attached to surface-modified titanium. J Periodontal Implant Sci 45: 38-45, 2015. https://doi.org/10.5051/jpis.2015.45.2.38

24. Uhl A, Völpel A, Sigusch BW: Influence of heat from light curing units and dental composite polymerization on cells in vitro. J Dent 34: 298-306, 2006. https://doi.org/10.1016/j.jdent.2005.07.004

25. Shortall AC, Harrington E: Temperature rise during polymerization of light-activated resin composites. J Oral Rehabil 25: 908-913, 1998. https://doi.org/10.1046/j.1365-2842.1998.00336.x

26. Bahrololoomi Z, Soleimani AA, Jafari N, Varkesh B: Micro-leakage of a fissure sealant cured using quartztungsten-halogen and plasma arc light curing units. J Dent Res Dent Clin Dent Prospects 8: 252-255, 2014. https://doi.org/10.5681/joddd.2014.045

27. Gorgidze LA, Oshemkova SA, Vorobjev IA: Blue light inhibits mitosis in tissue culture cells. Biosci Rep 18: 215-224, 1998. https://doi.org/10.1023/A:1020104914726

28. Ohara M, Fujikura T, Fujiwara H: Augmentation of the inhibitory effect of blue light on the growth of B16 melanoma cells by riboflavin. Int J Oncol 22: 1291-1295, 2003. https://doi.org/10.3892/ijo.22.6.1291

29. Lewis JB, Wataha JC, Messer RL, Caughman GB, Yamamoto T, Hsu SD: Blue light differentially alters cellular redox properties. J Biomed Mater Res B Appl Biomater 72: 223-229, 2005. https://doi.org/10.1002/jbm.b.30126

30. Sonis ST: The biologic role for nuclear factor-kappaB in disease and its potential involvement in mucosal injury 
associated with anti-neoplastic therapy. Crit Rev Oral Biol Med 13: 380-389, 2002.

31. Flemming KA, Cullum NA, Nelson EA: A systematic review of laser therapy for venous leg ulcers. J Wound Care 8: 111-114, 1999. https://doi.org/10.12968/jowc.1999.8.3.25848

32. Bjordal JM, Couppé C, Chow RT, Tunér J, Ljunggren EA: A systematic review of low level laser therapy with location-specific doses for pain from chronic joint disorders. Aust J Physiother 49: 107-116, 2003. https://doi.org/10.1016/S0004-9514(14)60127-6

33. Brosseau L, Welch V, Wells G, et al.: Low level laser therapy (classes I, II and III) in the treatment of rheumatoid arthritis.
Cochrane Database Syst Rev (2): CD002049, 2000. https://doi.org/10.1002/14651858.CD002049

34. Simões A, Platero MD, Campos L, Aranha AC, Eduardo Cde P, Nicolau J: Laser as a therapy for dry mouth symptoms in a patient with Sjögren's syndrome: a case report. Spec Care Dentist 29: 134-137, 2009.

35. Sicilia A, Cuesta-Frechoso S, Suárez A, Angulo J, Pordomingo A, De Juan P: Immediate efficacy of diode laser application in the treatment of dentine hypersensitivity in periodontal maintenance patients: a randomized clinical trial. J Clin Periodontol 36: 650-660, 2009.

https://doi.org/10.1111/j.1600-051X.2009.01433.x 